\title{
Identifying Tools and Techniques for Managing Construction Project Delivery in Small and Medium Enterprises in South African Construction Industry
}

\author{
*Justus Ngala Agumba, Ferdinand Cedric Fester \\ University of Johannesburg corner Siemert and Beit Streets, Doornfontein, Johannesburg, South Africa. \\ jagumba@uj.ac.za
}

\begin{abstract}
The purpose of this study was to assess the management tools and techniques that are used to manage time, cost and quality and determine if the management tools and techniques used were effective in managing time, cost and quality. Fifteen small and medium construction enterprises accepted to be interviewed after they were purposively sampled in Gauteng province in the city of Johannesburg, South Africa. This study reports the findings of in-depth structured interviews with directors and construction managers of the small and medium construction enterprises. The results were analysed using content analysis and the findings reveal that the management tools and techniques used to manage time were bar charts or networks; in managing cost, cash flow and cost breakdown structure or bill of quantity, and in managing quality, inspection of work and specifications. The respondents agreed that in using these management tools and techniques they were able to effectively manage their projects and attained the targets set.
\end{abstract}

Keywords: management, tools, techniques, small, medium, qualitative approach

\section{Introduction}

Construction industry in many developing countries worldwide comprise of many stakeholders, procurement systems, management philosophies, techniques and tools that play significant roles in the development of infrastructure for these countries, such as roads, schools and hospitals. Small and medium enterprises (SMEs) comprise a significant component of the construction economy in developing countries and contribute to employment creation, because of their specialisation and relative low overheads, small and medium contractors form a good sub-contractor resource base from which, large established contractors draw (Dlungwana and Rwelamila, 2003). Miles (1997), Gounden (1997) and Van Wyk (2003) agree that small and medium construction enterprises (SMEs) are vital drivers for economic growth. The National Small Business Act 1996 in South Africa, amended in 2004 defines small contractors as those with a total turnover of between $\mathrm{R} 3 \mathrm{~m}$ and $\mathrm{R} 6 \mathrm{~m}$, a total number of full time paid employees between 20 and 50 and a total gross asset value (fixed property) of between R0.5m and R1m, whereas medium contractors are defined as having a total turnover of between R6m and R26m, total full time paid employees between 50 and 200 and have a total gross asset value (fixed property) of between $\mathrm{R} 1 \mathrm{~m}$ and $\mathrm{R} 5 \mathrm{~m}$.

Poor contractor performance and its causes: In South Africa, the White Paper on Creating an Enabling Environment for the Construction Industry of 1999, describes the South African SME sector as largely underdeveloped and lacking the managerial and technical skills and the sophistication enjoyed by larger, well established contractors (DPW, 1999).

Despite the mooted programmes by the South African government many problems are faced by contractors when delivering construction projects. As a result poor contractor performance, as characterized by poor work quality and low productivity, is common in the industry (Dlungwana et al. 2002). In a survey conducted by Smallwood, (2000) among South African Property Owners Association (SAPOA) to investigate the client's perception relative to contractors' performance, Smallwood found that the predominant problems were rework and poor productivity and poor quality of work. Smallwood concluded that the causes of poor contractor performance, as perceived by clients, were lack of concern for the environment, late information, poor management of the design activities, inadequate or poor planning, poor management and low skills level among the workers.

Other writers (Allens, 1994; Henry, 1994) strongly concur with Smallwood's results. Furthermore, they identified further problems to be cost over-run, rework, late completion and unacceptably high accident rate, insensitivity to environmental considerations, poor work practices and adversarial relationship. 
Nkado and Mbachu (2002) also note that clients' are dissatisfied on there final product in the South African construction industry and also in the other parts of the world as highlighted by (Kometa et al. 1994). The poor image of small and medium enterprises (SMEs) in the construction industry in South Africa in terms of infrastructure delivery, stem's from failure of the contractors having poor estimating abilities and hence make unrealistic delivery promises, in order to secure a contract. As a result, the contractor does not start or complete the project on time and must compromise on quality in order to make an acceptable profit or vice versa (Weisswange, 1997). Nkado and Mbachu (2002) indicates that the current and future prospects in the construction industry depend on the extend to which building clients are satisfied with the outcomes of the investment in the building procurement process, the reported prevalence of client dissatisfaction detracts from the viability and sustenance of the construction industry as a whole.

As a result of these failures, Mongalo Thato national training coordinator of the National Home Builders Registration Council (NHBRC) estimates that most homebuilders have a life span of six months in the industry due to lack of professionalism and sustainability as they experience cash flow problems in their projects and thus have to leave the industry (Gillam, 2004). In order to bridge these gap of poor performance in project delivery the following research questions were formulated to address the management tools and techniques that are used to manage time, cost and quality in projects undertaken by SMEs;

- What are the characteristics of SME?

- What are the management tools and techniques that are used for managing time, cost and quality by SME?

- How effective are the management tools and techniques in managing time, cost and quality in SME projects?

\section{Literature review}

According to Miles (1997) the construction industry operates in a complex and generally project specific environment, Agumba, (2006) further indicates that the industry is dynamic and thus each project may involve the assembly of role players and resources that may be specific for that project only. Apart from what has been mentioned above, Burke (1999) indicates that rapidly changing technology, fierce competition in the market and a powerful environment lobby, has all encouraged companies to change their management systems and adopt project management.

Faniran (1999) and Miles, (1997) argue that project environment in many developing countries presents special challenges for project managers that almost presuppose extensive cost and time overruns even before the project commence. These challenges arise mainly due to inherent risks such as political instability, excessive bureaucratic contract procedures and the lack of adequate infrastructure. In recognition of these problems, there is a need to develop appropriate management tools and techniques specifically tailored to the project environment of developing countries. Faniran, (1999) further indicates the need to develop a body of knowledge on management tools and techniques for successful management of construction projects in developing countries, taking into account the operating conditions within the local industry.

Bates et al. (1999) notes that more than two hundred (200) years ago a mason was both designer and manager on a building site but today the construction industry of the world is fragmented into a multiplicity of trades, skills, professions and functional groups. This fragmentation has brought with it great benefits to the industry as a whole, but has resulted in a variety of new problems related to coordination, planning and interface relationships. As a result of this, it can be indicated that there is a need for managing projects in phases and hence implementing management tools and techniques during the phases of the projects, to manage time, cost and quality successfully.

Managing time: Project sequence is a finite, time-ordered and interrelated set of tasks. The project end date may not be known for a long time, but it is assumed that it will end and it is expected to end. Time presents a framework for the management of the project sequence and also a driving force behind the project. The management of time by networks such as the critical path method is a critical characteristic 
of project management. As the project proceeds there is a build up of greater detail in control of time and, hence, progressive elaboration is needed (Healy, 1997).

Planning is not synonymous with small building projects. This is caused by the nature of some small projects which are difficult, and sometimes impossible, to plan. This does not mean that planning is not applicable to small works. Short-term planning may be useful to the organisation and management of individual subcontractors, whilst long term and medium term planning techniques are certainly recommended for small fixed-term contracts (Weisswange, 1997). Some of the time management techniques that will be used for planning, scheduling and controlling the project will be bar charts/Gantt charts, networks (critical path network), earned value analysis, progress reporting and work breakdown structure (Burke, 2007).

Managing cost: Cost is usually an important factor and therefore a section indicating the target budget is usually a good thing. A budget is prepared for each task and by adding up all the tasks you have a cash flow envelope. The actual expenditure of the project has now to be monitored and compared with the actual flow of the cash in the budget. If there are any tasks that frequently experience cost overruns, an investigation should be undertaken; likewise when some tasks are well under the budget an investigation should be conducted (Reiss, 1992). When planning and monitoring cost, one needs to check the way in which the system provides for this need. The systems being used should be handled with care. The allocation of costs to tasks and perhaps to resources may require one to be able to total the costs of part of the project and for the whole project. One should have the ability to enter actual costs with the original budget (Reiss, 1992). Hore et al. (1997) argue that by maintaining a continuous check on production costs for cost-control purposes, the project cost system yields valuable information needed for the estimating of the costs of future construction work. Average production rates and unit costs are obtained from complete projects and are maintained in permanent files. These records of past experience are an individual resource for the estimator when new projects are being priced (Hore et al. 1997).

Good cost control therefore entails good management which take cognisance of good cost planning in terms of a cash flow forecast. Good financial planning ensures that sufficient funding is available at the right time to meet the needs of the client or contractor for short, medium and long-term capital. Shortterm finance may need to be made available for the purchase of plant or machinery. In the medium or long-term the organization may need to finance the construction of a new head office. Planning the flow of cash in the organization is one of the major functions of management. The necessity of using the right personnel and management techniques is vital in order for one not to experience incorrect cash flow that might lead to loss of profit and the subsequent failure of a company (Hore et al. 1997). The process of preparing a cash flow involves predicting cash flows for individual projects, which, in turn, are amalgamated into the master cash flow for the company. The master cash flow will also provide for those general overheads, which cannot be allocated to individual projects. In order to prepare a cash flow forecast information required will be the contract budget in monthly or cumulative form, contract period, payment periods, retention details, defects liability period, anticipated profit release and delay in meeting the cost committed (Hore et al. 1997).

Managing quality: The bitterness of quality remains long after the sweetness of meeting the schedule has been forgotten (Reiss, 1992). Quality planning and control is concerned with the techniques and activities which sustain quality to specified requirements. It is the practical means of sectoring products and services as laid down in a product specification. The basis of quality control is inspection. The outcome of this statement is that quality control is an after the fact activity which measures a product that has not been produced to customer satisfaction. Defects will be detected by post-production inspection using quality control systems rather than being prevented (Bell et al. 1997).

According to Bell et al. (1997) since quality control is essentially not a prevention-based system, the process of measuring, examining, testing and comparing with relevant standards must be accurate and precise. Employing more inspectors and detecting more defects does not promote or improve quality in the medium or long term. It is believed that the inspection process is costly and adds no value to the organisation or the product. Even if all the defective parts are removed before delivery to the customer, the cost of incurring the defective products in the first place will be passed to the customer in some way (Bell et al., 1997). Hauptfleisch (1999) further states that quality control is of equal importance to refurbishments, alterations, repairs, maintenance and even "re-do" work. 
According to Alshawi and Ingirige (2003), reworking or redoing the work may be caused by conflicting information not received in time by the parties concerned. They further state that the projects are normally managed according to the experience of the project managers who are specifically appointed for this task. Each project manager, even within the same organization, prefers to follow his/her own experience, which has been developed over a long period of time. These practices lead to large variations in management practices which can have a significant impact on the ability to coordinate and control project information in order to achieve the desired results.

According to Wessel (2002), costs of quality are incurred throughout the construction process with some easily identified while others are difficult to define and quantify. Costs are incurred before the actual construction of the building. Prevention costs have to be investigated. Bell et al., (1997) further indicates that in any project, total quality management will focus on the interaction of the external customer, the external supplier, stockholders, society at large and the organisation itself and, specifically, on the effective and efficient management of the process to satisfy the needs of the enterprise. For the services and products to be delivered on time, at the projected budget and to the right quality there must be an internal customer relationship.

Problem Statement: The overriding research problem is to identify the management tools and techniques that are used and if they are effective in managing time, cost and quality in SMEs projects in the South African construction industry. The study focused on small and medium construction enterprises in Gauteng province in South Africa.

Objectives of the research: To answer the aforementioned research questions. This research delved on the following specific objectives:

- To determine the characteristic of the SMEs;

- To identify the type of management tools and techniques used by SMEs in managing time, cost and quality; and

- To determine the effectiveness of using the management tools and techniques in managing time, cost and quality

\section{Methodology}

This study adopted a qualitative methodology using structured interviews. The structured interview was based on the profile of the enterprise, the type of management tools and techniques used by the respondents and their effectiveness in achieving the targets set of time, cost and quality. This was to unearth any detailed information that is required from the respondents in managing time, cost and quality.

Fifteen SMEs managed by either directors/owners or construction managers were carefully selected to reflect the objective of the study, the respondents were called telephonically after there enterprises were purposively selected from the web-site of Gauteng Master Builders Associations, which is a voluntary organization, some were registered with National Home Builders Registration Council which is a South Africa's home building regulator. The respondents were 10 (ten) small and 5 (five) medium construction enterprises from Gauteng province in the city of Johannesburg. The interviewees were given assurance on confidentiality of data and identity. On average, each interview lasted approximately $1 \frac{1}{2}$ hour. The respondents choose to have the interviews in their premises. This allowed them to participate in the interviews while conducting the business activities. In cases where the respondents were asked to illustrate and substantiate a particular issue, they obliged to comply. Extensive notes were taken on the open ended questions as the structured questions were administered before the open ended questions. Upon completion, the interviewing notes were transcribed, shown and discussed with the interviewee for accuracy and completion. This process was repeated before conducting the next interview. The whole interviewing cycle took six weeks.

The sampling design that was adopted was non-probability sampling. This sampling technique does not show any bias in estimating the probability that each member of the population has of being included in the sample (Frankfort-Nachmias and Nachmias, 1994). The contractors were deliberately chosen to be representative of small and medium construction enterprise. Kothari (1995) indicates that, when using non-probability sampling, the researchers purposively choose the particular units of the population, 
which constitute the sample on the basis, that the small mass that they select will be typical or representative of the whole population. Walliman (2001) also believes that purposive sampling gives the researcher a typical sample to rely upon in terms of in-depth study of the form and substance of a phenomenon. The structured questions were analyzed using the Microsoft excel statistical method. This resulted in the computation of percentage response of the enterprise profile. The open-ended interviews, which were structured, were transcribed and analysed using content analysis as summarised in Table $1 \& 2$ and statistically summarised in Tables: $3,4,5,6,7 \& 8$.

\section{Results}

Table 1 and Table 2, is a summary of details of the fifteen interviews. Table 1 reflects the management tools and techniques used to manage, time, cost and quality. Table 2 summarises the effectiveness of using these tools and techniques for managing time cost and quality.

Table 1: Management tools and techniques for managing time, cost and quality

\begin{tabular}{|c|c|c|c|}
\hline Respondent & $\begin{array}{l}\text { Tool(s) \& Technique(s) } \\
\text { used to manage time }\end{array}$ & $\begin{array}{l}\text { Tool(s) and Technique(s) used } \\
\text { to manage cost }\end{array}$ & $\begin{array}{l}\text { Tool(s) and } \\
\text { technique(s) used to } \\
\text { manage quality }\end{array}$ \\
\hline $\begin{array}{l}\text { Respondent } \\
1\end{array}$ & Bar chart & $\begin{array}{l}\text { Lump sum contract bills of } \\
\text { quantity }\end{array}$ & $\begin{array}{l}\text { Set quality standards } \\
\text { (specifications) }\end{array}$ \\
\hline $\begin{array}{l}\text { Respondent } \\
2\end{array}$ & $\begin{array}{l}\text { Ms project, critical path } \\
\text { method, bar chart }\end{array}$ & Bills of quantity (BOQ) & $\begin{array}{l}\text { Inspection, } \\
\text { standards } \\
\text { specification }\end{array}$ \\
\hline $\begin{array}{l}\text { Respondent } \\
3\end{array}$ & $\begin{array}{l}\text { Bar charts, critical path } \\
\text { method (CPM) to plan the } \\
\text { projects }\end{array}$ & Budget as in bills of quantity & $\begin{array}{l}\text { Inspection standards } \\
\text { and specification }\end{array}$ \\
\hline $\begin{array}{l}\text { Respondent } \\
4\end{array}$ & None & $\begin{array}{l}\text { Work with clients cost hence } \\
\text { paid in stages as per the } \\
\text { agreement }\end{array}$ & $\begin{array}{l}\text { Specification } \\
\text { standards form the } \\
\text { client }\end{array}$ \\
\hline $\begin{array}{l}\text { Respondent } \\
5\end{array}$ & Bar chart, CPM & Actual cost of work v/s budgeted & $\begin{array}{l}\text { Good specification and } \\
\text { standards }\end{array}$ \\
\hline $\begin{array}{l}\text { Respondent } \\
6\end{array}$ & None & Submit an invoice for payment & $\begin{array}{l}\text { Specifications } \\
\text { Quality control }\end{array}$ \\
\hline $\begin{array}{l}\text { Respondent } \\
7\end{array}$ & Program bar chart & $\begin{array}{l}\text { Prepare interim payments, cost } \\
\text { breakdown }\end{array}$ & $\begin{array}{l}\text { Standards set } \\
\text { specification given }\end{array}$ \\
\hline $\begin{array}{l}\text { Respondent } \\
8\end{array}$ & Bar chart & $\begin{array}{l}\text { Check actual v/s budgeted. Cash } \\
\text { flow \& cost report }\end{array}$ & $\begin{array}{l}\text { Specifications from } \\
\text { client or architect }\end{array}$ \\
\hline $\begin{array}{l}\text { Respondent } \\
9\end{array}$ & Bar chart & $\begin{array}{l}\text { Progress of cost, interim } \\
\text { payments, check actual v/s } \\
\text { budgeted cost }\end{array}$ & $\begin{array}{l}\text { Procedures, standards } \\
\text { and specifications }\end{array}$ \\
\hline $\begin{array}{l}\text { Respondent } \\
10\end{array}$ & $\begin{array}{l}\text { Method statement, ms } \\
\text { project }\end{array}$ & $\begin{array}{l}\text { Cost report of work done \& work } \\
\text { budgeted for }\end{array}$ & $\begin{array}{l}\text { Check for standards } \\
\text { and specifications }\end{array}$ \\
\hline $\begin{array}{l}\text { Respondent } \\
11\end{array}$ & Bar chart/ CPM & $\begin{array}{l}\text { Cost reporting using CPM to } \\
\text { anticipated the cost to date }\end{array}$ & $\begin{array}{l}\text { Good specifications } \\
\text { and inspection }\end{array}$ \\
\hline $\begin{array}{l}\text { Respondent } \\
12\end{array}$ & $\begin{array}{l}\text { Meetings to prepare the } \\
\text { program }\end{array}$ & $\begin{array}{l}\text { Monitor cost on a weekly basis. } \\
\text { Cost report }\end{array}$ & $\begin{array}{l}\text { Good specifications } \\
\text { and inspection }\end{array}$ \\
\hline $\begin{array}{l}\text { Respondent } \\
13\end{array}$ & $\begin{array}{l}\text { Prepare a bar chart, } \mathrm{CPM} \\
\text { to mange time }\end{array}$ & $\begin{array}{l}\text { Measure work on site and } \\
\text { compare to the program to know } \\
\text { the cost of payment to date }\end{array}$ & $\begin{array}{lr}\text { Inspection of } & \text { work, } \\
\text { standards } & \& \\
\text { specification set } & \end{array}$ \\
\hline $\begin{array}{l}\text { Respondent } \\
14\end{array}$ & Program & Check work done v/s budgeted & $\begin{array}{l}\text { Set specifications \& } \\
\text { standards }\end{array}$ \\
\hline $\begin{array}{l}\text { Respondent } \\
15\end{array}$ & $\begin{array}{l}\text { Program in the form of a } \\
\text { bar chart }\end{array}$ & $\begin{array}{l}\text { Claim on a fortnight basis and } \\
\text { counter with the program }\end{array}$ & $\begin{array}{l}\text { Set standards } \\
\text { specifications }\end{array}$ \\
\hline
\end{tabular}
Source: (Field interviews) 
Table 2: Effectiveness of using the management tools and techniques for managing time, cost and quality

\begin{tabular}{|c|c|c|c|}
\hline Respondent & $\begin{array}{l}\text { Effectiveness of using } \\
\text { time management tool(s) } \\
\text { and technique(s) }\end{array}$ & $\begin{array}{l}\text { Effectiveness of using } \\
\text { cost management } \\
\text { tool(s) technique(s) }\end{array}$ & $\begin{array}{l}\text { Effectiveness of using } \\
\text { quality management } \\
\text { tool(s) and technique(s) }\end{array}$ \\
\hline $\begin{array}{l}\text { Respondent } \\
1\end{array}$ & It was Ineffective & $\begin{array}{l}\text { Effective no cost overrun } \\
\text { experienced }\end{array}$ & Effective in the projects \\
\hline $\begin{array}{l}\text { Respondent } \\
2\end{array}$ & $\begin{array}{l}\text { Effective as one will know if } \\
\text { they are lagging behind or } \\
\text { not }\end{array}$ & $\begin{array}{l}\text { Effective for the nature of } \\
\text { the projects }\end{array}$ & Not $100 \%$ effective \\
\hline $\begin{array}{l}\text { Respondent } \\
3\end{array}$ & Very effective. & $\begin{array}{l}\text { Effective for planning and } \\
\text { controlling the project } \\
\text { cost }\end{array}$ & $\begin{array}{l}\text { Quality is achieved hence } \\
\text { effective }\end{array}$ \\
\hline $\begin{array}{l}\text { Respondent } \\
4\end{array}$ & Not effective & $\begin{array}{l}\text { Need improvement } \\
\text { because no proper } \\
\text { management }\end{array}$ & $\begin{array}{l}\text { Need for improvement as } \\
\text { they experience dispute }\end{array}$ \\
\hline $\begin{array}{l}\text { Respondent } \\
5\end{array}$ & $\begin{array}{l}\text { Experience delays hence } \\
\text { needs improvement }\end{array}$ & $\begin{array}{l}\text { Need updating to be more } \\
\text { efficient }\end{array}$ & $\begin{array}{l}\text { Effective as one will detect a } \\
\text { problem. }\end{array}$ \\
\hline $\begin{array}{l}\text { Respondent } \\
6\end{array}$ & Effective. & Happy with the system & $\begin{array}{l}\text { Quite effective as no much } \\
\text { defects are experienced }\end{array}$ \\
\hline $\begin{array}{l}\text { Respondent } \\
7\end{array}$ & $\begin{array}{l}\text { Effective as they do not } \\
\text { experience enormous delay }\end{array}$ & Effective & Improvement is required \\
\hline $\begin{array}{l}\text { Respondent } \\
8\end{array}$ & The technique is effective & $\begin{array}{l}\text { Effective as one can } \\
\text { establish the cost overrun }\end{array}$ & $\begin{array}{l}\text { Effective in tracking good } \\
\text { workmanship and material }\end{array}$ \\
\hline $\begin{array}{l}\text { Respondent } \\
9\end{array}$ & $\begin{array}{l}\text { Needs to be improved, but } \\
\text { effective }\end{array}$ & $\begin{array}{l}\text { Not very effective needs } \\
\text { to be improved }\end{array}$ & $\begin{array}{l}\text { Effective method } \\
\text { managing quality }\end{array}$ \\
\hline $\begin{array}{l}\text { Respondent } \\
10\end{array}$ & Effective & Effective & Achieve good results \\
\hline $\begin{array}{l}\text { Respondent } \\
11\end{array}$ & Effective no delays & Effective & Effective \\
\hline $\begin{array}{l}\text { Respondent } \\
12\end{array}$ & Effective no delays & Not very effective & Effective for quality on site \\
\hline $\begin{array}{l}\text { Respondent } \\
13\end{array}$ & $\begin{array}{l}\text { Very effective as they can } \\
\text { anticipate any problems }\end{array}$ & $\begin{array}{l}\text { Effective in establishing } \\
\text { cost problems }\end{array}$ & $\begin{array}{l}\text { Not very effective as there } \\
\text { are disputes }\end{array}$ \\
\hline $\begin{array}{l}\text { Respondent } \\
14\end{array}$ & $\begin{array}{l}\text { Needs improvement, but } \\
\text { effective }\end{array}$ & $\begin{array}{l}\text { Need to be improved to } \\
\text { current situations }\end{array}$ & Not $100 \%$ happy \\
\hline $\begin{array}{l}\text { Respondent } \\
15\end{array}$ & $\begin{array}{l}\text { Quite effective as one is } \\
\text { able to track down the } \\
\text { progress }\end{array}$ & $\begin{array}{l}\text { Cost overrun } \\
\text { experienced }\end{array}$ & tive \\
\hline
\end{tabular}

Source: (Field interviews)

Discussions of results: The interviewees' responses to the questions asked during the interview sessions are discussed in the following section.

Characteristics of the profiled sample: The $66.67 \%$ of the respondents interviewed were managing directors, $26.67 \%$ were construction managers and $6.67 \%$ were quantity surveyors. The respondents were involved in planning for their projects at present. This result suggests that majority of SMEs are managed by managing directors who are owners of the organizations, a typical characteristic of this sector of business.

$66.67 \%$ of the SMEs interviewed are in the field of building construction business, while $26.67 \%$ of the contractors were involved in home improvement and $6.67 \%$ contractor was involved in commercial projects. This suggests that SMEs who engage in home improvement and commercial properties are quite few. From the result it can therefore be indicated that majority of small and medium construction enterprises are involved in building construction projects. $66.67 \%$ of the organizations interviewed were 
small contractors and 33.33\% were medium contractors. This was in line with the requirement for this research.

$73.33 \%$ of the respondents had more than ten years experience in their current position, whereas $26.67 \%$ of the respondents had between one (1) year and six (6) years of experience. This result indicates that there is ample experience among the respondents interviewed. The result signifies the essence of managing small and medium construction companies with experienced personnel.

$13.33 \%$ of the respondents had a matric qualification and below whereas the other $86.67 \%$ personnel interviewed had a tertiary qualification i.e. from diplomats to post graduate qualifications. Thus the projects undertaken by SMEs are being managed and run by qualified personnel. At the time of this interviews the respondents had completed an average of six (6) projects per year and the average value of the largest project completed was R8 million working and were involved on average with three (3) projects at an estimated value of R5 million on average. The information gathered at pertaining to the sample profile was adequate enough to gather the required data of this research project.

Management tools and techniques for managing time, cost and quality and the effectiveness when used: 6.2.1 Usage and effectiveness of management tools and techniques in managing project time

From the result indicated in Table 3, majority of the respondents used a technique to manage their projects in terms of time. It can be seen that $80 \%$ of respondents interviewed, prepared a management technique to manage their project time. $20 \%$ of the respondents did not prepare any form of management technique, they used intuition i.e. experience to guide them in decision-making. Bar charts featured prominently amongst the respondents as $80 \%$ alluded to have been using it whereas critical path network is seen as probably not being embraced fully by the SMEs in managing their time as only $33.33 \%$ respondents attested to it. This result concurs with Faniran (1999), and Bates et al, (1999).

The contractors who used these techniques were so articulate in their response. From the result in Table 4 using the bar chart or critical path network assisted $76.92 \%$ of the respondents in achieving there target set time of the project but $23.08 \%$ of them felt there is need to improve the use of their management technique. This result addresses the research objective three (3). The result indicates there is usage of management tools and techniques to manage time and they are effective when used to manage the projects targets set. The other $20 \%$ of respondents who used intuition were not considered to have used a management technique in managing time.

Table 3: Management tools and techniques for managing time

\begin{tabular}{ll}
\hline Management tool and techniques used & $\begin{array}{l}\text { Percentage of respondents using the tools } \\
\text { and techniques }\end{array}$ \\
\hline Bar chart (Gantt chart) & $80.00 \%$ \\
Critical Path Network & $33.33 \%$ \\
\hline
\end{tabular}

Table 4: Effectiveness of using the management tools and techniques in managing time

\begin{tabular}{lll}
\hline $\begin{array}{l}\text { Project management tool } \\
\text { and techniques }\end{array}$ & $\begin{array}{l}\text { Effectiveness of the tools and } \\
\text { techniques }\end{array}$ & Not effective \\
\hline $\begin{array}{l}\text { Bar chart (Gantt chart) and } \\
\text { Critical Path Network }\end{array}$ & $76.92 \%$ & $23.08 \%$ \\
\hline
\end{tabular}

\subsubsection{Usage and effectiveness of management tools and techniques in managing project cost}

From the result in Table 5, all respondents 100\%, interviewed used a form of project management tools and techniques to enable them budget for their construction projects. Cost breakdown structure that was frequently used was in the form of bills of quantities, which was articulated by the SMEs. The provision of a cost report to enable the contractor manage his finances was evident amongst the respondents as $60 \%$ of the alluded to using it. The cost report enabled the respondents to trace their cash flow, and was vital to ensure proper cost reconciliation of the project. Weisswange (1997) agrees with this result that majority of SMEs use project management control techniques to manage their projects cost. 
In respect of the effectiveness of using these techniques Table 6, 60\% of the contractors achieved the results i.e. they never experienced any cost overrun and any difficulties in managing their cost using the project control techniques they stated. Whereas $33.33 \%$ of the contractors felt that their companies need to update their techniques so as to be more efficient and effective to bring more success. They never experienced cost overrun but they felt the need to update their techniques of managing their project cost. This might have been caused by, lack of personnel to use the available techniques adequately which might have been cumbersome for the contractors. $6.67 \%$ of respondents prepared a quotation, which he/she felt needs to be improved. This quotation might not have been adequately prepared to enable the contractor to trace his project cost despite not experiencing any cost overrun. Inadequate preparation of the cost breakdown document might have also created difficulties in managing the cost of this respondents' project. This result answers the research objective 3 (three).

Table 5: Management tools and techniques for managing cost

\begin{tabular}{llll}
\hline Management tools and techniques used & $\begin{array}{l}\text { Percentage of } \\
\text { techniques }\end{array}$ & respondents using the \\
\hline Cost breakdown structure (bill of quantity) & $100.00 \%$ & & \\
Cost report & $60.00 \%$ & & \\
Cash flow & $53.30 \%$ & & \\
\hline
\end{tabular}

Table 6: Effectiveness of using management tools and techniques in managing cost Management tools and Effectiveness of the techniques Not very effective techniques

Cost breakdown structure $60 \% \quad 40 \%$

(bill of quantity), cost report

and Cash flow

\subsubsection{Usage and effectiveness of management control techniques in managing project quality}

From the result in, Table 7, all respondents interviewed agreed to have been using a quality management technique to manage their projects. Jenkins (1999) agrees with this result. All the respondents in managing their projects used specifications and standards; this is due to the fact that, specification is drafted by an architect on behalf of the client as part of the tender document. On any project, especially in construction projects they will have a specification and standard set for a project, as this is a benchmark for ordering of the required material and the workmanship of the activities. According to the respondents the specification and standards were specified to them and in case of any changes they were informed. The use of the technique is evident, as the contractor would have to meet the client's needs in terms of good quality product. Bell et al. (1997), concurs with this result.

$100 \%$ of the respondents used inspection of work as a project management tool and technique to manage quality, to enable them achieve good quality work. $33.33 \%$ of the contractors felt they need to improve their quality management techniques. The specifications should be in line with the project requirements, if not carried out to the specification at hand the contractors have to correct the mistake if caused by them. If materials ordered are not to the required specification the contractor has to reorder the material to meet the requirements of the project.

From the result in Table 8 using specification and standards, and inspecting the work is effective in achieving the results of the small and medium contractor's projects as $66.67 \%$ of the SMEs agreed that the techniques were effective. Inspection and specifications are used for any kind of project not necessarily new buildings but is of equal importance to the contractors who are carrying out projects of refurbishment and renovations i.e. home improvement as some of the small contractors were involved in these projects. All the contractors rectified their work in case there was a defect. The defects were detected during inspection of work by the respondents, it is therefore of paramount importance that the work is properly inspected in order for the contractors to be able to detect any defects in the work they are carrying out. Hence this discussions address research, objective three (3).

Table 7: Management tools and techniques for managing quality

\begin{tabular}{lll}
\hline Management tools and techniques used & $\begin{array}{l}\text { Percentage of respondents using the } \\
\text { technique }\end{array}$ & \\
\hline Standards and specifications & $100 \%$ & \\
\hline
\end{tabular}


Table 8: Effectiveness of using the management tools and techniques

\begin{tabular}{lll}
\hline $\begin{array}{l}\text { Management tools and } \\
\text { techniques }\end{array}$ & $\begin{array}{l}\text { Effectiveness of using the } \\
\text { techniques }\end{array}$ & Not very effective \\
\hline $\begin{array}{l}\text { Standards and specifications, } \\
\text { Inspection of work }\end{array}$ & $66.67 \%$ & $33.33 \%$ \\
\hline
\end{tabular}

\section{Conclusions}

From the findings of this research small and medium construction enterprises used the management tools and techniques. The management tools and technique used frequently for managing time is a bar chart, whereas critical path network was seldom used. Bill of quantity was used frequently to manage cost, whereas inspection of work, specifications and standards were used frequently to manage quality of work. It can also be stated that the SMEs who used the management tools and techniques achieved the required results of time, cost and quality, hence the management tools and techniques were deemed to be effective. In conclusion, managing of construction projects by SMEs to achieve the clients' objective and theirs will depend on the SMEs using the management tools and techniques effectively to trace faults and progress in the projects. However, the multiple data collection method of interviews, inspections and further inquiries helped to minimize the threats to validity and reliability of information. Further, even though this study focused on in-depth understanding of the type of the management tools and techniques used and their effectiveness in managing time, cost and quality, the fifteen selected respondents may not necessarily reflect the approaches adopted by the directors and construction managers as a whole in other parts of the country, hence this is a major limitation of the study. More empirical research of a country wide survey could help firm up the understanding and reasons for selecting the management tools and techniques stated and if they are effective in improving the project parameters of time, cost and quality. Finally the tools and techniques stated is an indication that most SMEs will be comfortable in using them and hence can be tailored for managing projects undertaken by small and medium construction enterprises in South Africa construction industry.

\section{References}

Agumba, J. N. (2006). Evaluating the use of Project Management Techniques in Infrastructure Delivery by South African Small and Medium Sized Contractors. Unpublished Masters Dissertation, Faculty of Engineering and the Built Environment, University of Johannesburg, South Africa.

Allens, A. R. (1994). Quality management in the construction phase of the traditional procurement system in South Africa: The case of the Western Cape; University of Cape Town in Cape Town, Western Cape, South Africa.

Alshawi, M. \& Ingirige, B. 2(003). Web-enabled project management: An Emerging Paradigm in Construction. Automation in construction, 12, 349-364.

Bates, M. B., Sturges, J. L. \& Hutchinson, B. (1999). Project Management Techniques and Procedures: A comparison of construction contracting and aircraft manufacture. Proceedings of the $2^{\text {nd }}$ International Conference on Construction Industry Development, and $1^{\text {st }}$ Conference of CIB TG 29 on Construction in Developing Countries, 27th-29th October, The Pan Pacific, Singapore. (http://buildnet.csir.co.za/cdcproc/1st_proceedings.html) last viewed on the 06/07/2011.

Bell, D., McBride, P. \& Wilson, G. (1994). Managing Quality. Published in association with the Institute of Management, Butterworth-Heinemann, Oxford.

Burke, R. (1999). Project Management: Planning and Control, (3rd ed), Published in the United Kingdom by John Wiley and Sons Ltd Baffins Lane Chichester, West Sussex, England.

Burke, R. (2007). Project Management: Planning and Control, Third Edition, Published in the United Kingdom by John Wiley and Sons Ltd Baffins Lane Chichester, West Sussex, England.

Department of Public Works, (1999). White paper on Creating an Enabling Environment for Reconstruction Growth and Development in the Construction Industry, Republic of South Africa. (http://www.info.gov.za/whitepaper/1999/environment.htm) last viewed on the 28/05/2011. 
Dlungwana, S. \& Rwelamila, P. D. (2003). The role of performance improvement tools in improving contractor performance in developing countries, Pretoria CSIR Boutek (http://buildnet.csir.co.za/cdcproc/docs/3rddlungwana.pdf) last accessed June 2011.

Dlungwana, S., Nxumalo, X. H., Huysteen S. V., Rwelamila, P. D. \& Noyana, C. (2002). Development and Implementation of the South Africa Construction Excellence Model. International conference on construction in the $21^{\text {st }}$ century (CITC) Challenges and opportunities in Management Technology, Miami Florida, USA, 25th-26th April 2002.

Faniran, 0. O. (1999). The role of construction project planning in improving project delivery in developing countries: case study of Nigerian construction industry. Proceedings of the $2^{\text {nd }}$ International Conference on Construction Industry Development, and $1^{\text {st }}$ Conference of CIB TG 29 on Construction in Developing Countries, The Pan Pacific, Singapore, 27th-29th October

Frankfort-Nachmias, C. \& Nachmias, D. (1994). Research Methods in the Social Sciences, (4th ed), Published by Biddles Ltd, Guildford and King's Lynn, Great Britain.

Gillam, S. (2004). SA Builder/Bouer, Awards for Excellence. Journal of the Building Industries Federation South Africa, 961, 28-29.

Gounden, S. M. (1997). Transforming public sector construction in South Africa-A focus on promoting small and medium construction enterprises. Paper Presented to the $1^{\text {st }}$ International Conference on Construction Industry Development, Singapore.

Hauptfleisch, A. C. (1999). Building Practice Volume 2, Published by Technikon SA, Florida, Republic of South Africa.

Healy, P. L. (1997). Project Management: Getting the Job done on time and in budget, ButterworthHeinemann, Melbourne, Australia.

Henry, A. L. (1994). The factors associated with insolvency among contractors in the South African construction industry: A case study of the Western Cape Region. University of Cape Town in Cape Town, South Africa.

Hore, A. V., Kehoe, J. G., McMullan, R. \& Penton, M. R. (1997). Construction 1: Management, Finance and Measurement, published by McMillan Press Ltd, Houndmills, London.

Jenkins, L. J. (1999). Implementing Quality Control Topics into the Building Construction Curriculum. ASC Proceedings of the 35th Annual Conference California Polytechnic State University- San Luis Obispo, California April $7^{\text {th }}-10^{\text {th }}$.

Kometa, S. T, Olomolaiye, P. O. \& Harris, F. C. (1994). Attributes of UK construction clients influencing project consultants performance. Construction management and economics, 12, 433-443.

Kothari, C. R. (1995). Research Methodology: Methods and Techniques, (2nd ed), Published by V. S. Johari for Wishwa Prakashan, New Delhi, India.

Miles, D. (1997). Appropriate Infrastructure: No choice but Change, paper presented to the $23^{\text {rd }}$ Water Engineering Development Conference (WEDC) on Water and Sanitation to all: Partnerships and Innovations. Durban, South Africa 426-429.

National Small Business Act (2004). Number 29 of 2004 Republic of South Africa. (http://www.seda.org.za/print.asp?subID=573) last viewed on the 18/04/2011

Nkado, R. N. \& Mbachu, J. I. C. (2002). Causes of and solutions to client dissatisfaction in the South African building industry: The client's perspectives. Creating a sustainable construction industry in developing countries, CIB W107 $1^{\text {st }}$ International conference $11^{\text {th }}$ to $13^{\text {th }}$ November 2002, Stellenbosch, South Africa.

Reiss, G. (1992). Project Management Demystified: Today's Tools and Techniques published by E \& FN Spon, London.

Smallwood, J. (2000). Contractor Performance: Clients' Perceptions. Proceedings of the CIB Task Group 29 (TG 29) on Construction in Developing Countries 128-139.

Van Wyk, L. (2003). A Review of the South African Construction Industry. Part 1: Economic, Regulatory and Public Sector Capacity Influences on the Construction Industry, CSIR website (http://www.csir.co.za/akani/200.PDF) accessed 18/04/2011.

Walliman, N. (2001). Your Research Project: A Step-by-Step Guide for the First-Time Researcher, (1st ed), published by SAGE Publications Ltd, London, England.

Weisswange, K. (1997). Project Control Techniques in the Management of Small and Medium Sized Building Companies. MBA Thesis, University of Witwatersrand, South Africa.

Wessel, J. (2002). Defining the critical success factors for the implementation and maintenance of a total quality management system in South African construction companies involved in building. MSc Dissertation, Project Management University of Pretoria, South Africa. 